Guest Editorial, part of a Special Feature on A Social-Ecological Analysis of Diversified Farming Systems: Benefits, Costs, Obstacles, and Enabling Policy Frameworks

\title{
Diversified Farming Systems: An Agroecological, Systems-based Alternative to Modern Industrial Agriculture
}

\author{
Claire Kremen $^{1}$, Alastair Iles $^{1}$ and Christopher Bacon ${ }^{2}$
}

\begin{abstract}
This Special Issue on Diversified Farming Systems is motivated by a desire to understand how agriculture designed according to whole systems, agroecological principles can contribute to creating a more sustainable, socially just, and secure global food system. We first define Diversified Farming Systems (DFS) as farming practices and landscapes that intentionally include functional biodiversity at multiple spatial and/or temporal scales in order to maintain ecosystem services that provide critical inputs to agriculture, such as soil fertility, pest and disease control, water use efficiency, and pollination. We explore to what extent DFS overlap or are differentiated from existing concepts such as sustainable, multifunctional, organic or ecoagriculture. DFS are components of social-ecological systems that depend on certain combinations of traditional and contemporary knowledge, cultures, practices, and governance structures. Further, as ecosystem services are generated and regenerated within a DFS, the resulting social benefits in turn support the maintenance of the DFS, enhancing its ability to provision these services sustainably. We explore how social institutions, particularly alternative agri-food networks and agrarian movements, may serve to promote DFS approaches, but note that such networks and movements have other primary goals and are not always explicitly connected to the environmental and agroecological concerns embodied within the DFS concept. We examine global trends in agriculture to investigate to what extent industrialized forms of agriculture are replacing former DFS, assess the current and potential contributions of DFS to food security, food sovereignty and the global food supply, and determine where and under what circumstances DFS are expanding rather than contracting.
\end{abstract}

Key Words: agroecology; ecological diversification; food justice; food sovereignty; industrialized agriculture

\section{INTRODUCTION}

The Special Feature on Diversified Farming Systems (Kremen et al. 1012a) is motivated by a desire to understand how agriculture designed according to whole-systems, agroecological principles can contribute to creating a more sustainable, socially just, and secure global food system. "How to feed the world" is an increasingly urgent and looming concern voiced by many people, from local community groups to national and international governing bodies. By 2050, the world population is projected to rise to $9+$ billion and food demands to double from current levels. At the same time, climate change, interacting with increasingly uneven access to declining oil, water, and phosphorus supplies, will greatly exacerbate the year-to-year unpredictability of agricultural production, potentially undermining the entire agricultural enterprise (Cribb 2010, Childers et al. 2011).

Meanwhile, industrialized agricultural techniques are exacting a huge toll on surrounding environments, polluting waterways, creating dead zones in the oceans, destroying biodiverse habitats, releasing toxins into food chains, endangering public health via disease outbreaks and pesticide exposures, and contributing to climate warming (Horrigan et al. 2002, Tilman et al. 2002, Diaz and Rosenberg 2008, Marks et al. 2010, Foley et al. 2011). Moreover, industrial agricultural methods are inherently unsustainable in mining soils (Lal
2004, Tegtmeier and Duffy 2005, Montgomery 2007) and aquifers (Gordon et al. 2008) far more quickly than they can be replenished, and in their high use of fossil fuels (Lynch et al. 2011). These numerous environmental and social externalities create a huge economic cost that industrialized food producers seldom pay. For instance, pesticide use alone causes up to $\$ 10$ billion in damage to humans and ecosystems in the United States every year (Pimentel 2005). Finally, although the agricultural sector currently produces more than enough calories to feed humanity, one billion people remain hungry and an additional one billion have micronutrient deficiencies (Welch and Graham 1999). This paradoxical situation occurs because many people still lack access to sufficiently diverse and healthy food, or the means to produce it, which is primarily a problem of distribution rather than production (IAAKSTD 2009). As further evidence of this paradox, global obesity rates have more than doubled since 1980 (WHO 2012), reflecting an overproduction of food in industrialized countries that creates strong incentives for agrifood companies to absorb excess food production into processed foods and to market and distribute them to customers in supersized portions (Nestle 2003).

This series of articles examines the proposition that diversified farming systems, with their focus on local production, local and agroecological knowledge, and whole systems approaches

\footnotetext{
${ }^{1}$ Department of Environmental Sciences, Policy and Management, University of California Berkeley, ${ }^{2}$ Department of Environmental Studies and Sciences, Santa Clara University
} 
reduce negative environmental externalities and decrease social costs associated with industrialized monocultures, enhance the sustainability and resilience of agriculture, and contribute significantly to global food security and health.

\section{DIVERSIFIED FARMING SYSTEMS DEFINED}

We refer to a farming system as "diversified" when it intentionally includes functional biodiversity at multiple spatial and/or temporal scales, through practices developed via traditional and/or agroecological scientific knowledge. Farmers manage this functional biodiversity to generate critical ecosystem services to agriculture (Zhang et al. 2007). At the plot (i.e., within-field) scale, diversified farming systems (DFS) may include multiple genetic varieties of a given crop and/or multiple crops grown together as polycultures, and may stimulate biodiversity within the soil through addition of compost or manure (Figure 1). By crops, we mean either annual or perennial crops, including tree crops. At the field scale, DFS may include polycultures, noncrop plantings such as insectary strips, integration of livestock or fish with crops (mixed cropping systems), and/or rotation of crops or livestock over time, including cover cropping and rotational grazing. Around the field, DFS may incorporate noncrop plantings on field borders such as living fences and hedgerows. At the landscape scale, DFS may include natural or semi-natural communities of plants and animals within the cropped landscape/region, such as fallow fields, riparian buffers, pastures, meadows, woodlots, ponds, marshes, streams, rivers, and lakes, or combinations thereof (see also Kremen and Miles 2012). The resulting heterogeneous landscapes support both desired (beneficial) components of biodiversity and "associated biodiversity"; together these two elements make up agrobiodiversity (Perfecto et al. 2005).

Components of the agrobiodiversity within DFS interact with one another and/or the physical environment to supply critical ecosystem services to the farming process, such as soil building, nitrogen fixation, nutrient cycling, water infiltration, pest or disease suppression, and pollination, thereby achieving a more sustainable form of agriculture that relies primarily upon inputs generated and regenerated within the agroecosystem, rather than primarily on external, often nonrenewable, inputs (Pearson 2007, Shennan 2008). Spatial considerations are important, since different components of the system must be in sufficient proximity, at each relevant scale, to create needed interactions and synergies. For example, the utility of intercropping for reducing belowground soil disease depends on spacing the different crops such that their root systems interact (Hiddink et al. 2010). Similarly, wild bee communities can only provide complete crop pollination services when a sufficient proportion of their natural habitat occurs within a given distance of crop fields (Kremen et al. 2004). A DFS is not only spatially heterogeneous, but is variable across time, due both to human actions (e.g., harvest, crop rotations, fallows, and other management practices or land use changes), and natural successional processes. Figure 1 presents the conceptual model of a DFS.

\section{AGROECOLOGY AND DFS}

The term agroecology goes back more than 80 years and originally referred to the ecological study of agricultural systems (Gliessman 2007). Much agroecological work seeks to bring Western scientific knowledge into respectful dialogue with the local and indigenous knowledge that farmers use in managing ecological processes in existing agroecosystems (Gliessman et al. 1981, Altieri and Toledo 2011). More recently this hybrid science has evolved to include the social and economic dimensions of food systems (Francis et al. 2003). Partly in response to the industrialized agriculture of the Green Revolution (Box 1), agroecology also came to mean the adoption of sustainable agricultural practices (see Box 2), and became an integral component of various social movements seeking alternatives to industrial agri-food systems. Thus agroecology currently holds multiple meanings, and can refer to an inter- or transdisciplinary science, a set of sustainable farming practices, and/or a social movement (Wezel et al. 2009). DFS is not an alternative to agroecology. Rather, DFS is a framework that draws from agroecological, social, and conservation sciences to focus analytical and action-oriented attention toward farming systems in which cross-scale ecological diversification is a major mechanism for generating and regenerating ecosystem services and supplying critical inputs to farming. Agroecological principles and methods can be used to evaluate DFS and to design or revive processes of diversification (Altieri 2002). In this essay and series of articles, we explore the ramifications of DFS for both ecological health and socioeconomic welfare, as well as examining the intersection of DFS with existing industrialized agricultural systems, supply chains, and national and international policies.

\section{Box 1:}

Industrialized agriculture versus DFS

Most industrialized agricultural systems contrast with DFS in their approaches to food production and managing production challenges. In general, industrial systems simplify ecosystems and utilize highly specialized, technical information with the goal of maximizing the profitability of a commodity crop or livestock on any given farm. Nonetheless, they do not necessarily maximize the total yield per land area or energy use (Rosset 1999, Hefland and Levine 2004, Lynch et al. 2011). Many, but not all, large-scale food and agricultural companies, government agencies, and some university research and extension programs treat farmers as users of large-scale, intensive technologies that can be applied universally across farms, irrespective of local variability and traditions of land management (Roling and Wagemakers 1998, Shennan 2008); in part, this may be responsible for lower net productivity per acre (Rosset 1999). The consolidated food industry often draws farmers into supply chains that ultimately 
Fig. 1. Conceptual model of a Diversified Farming System.
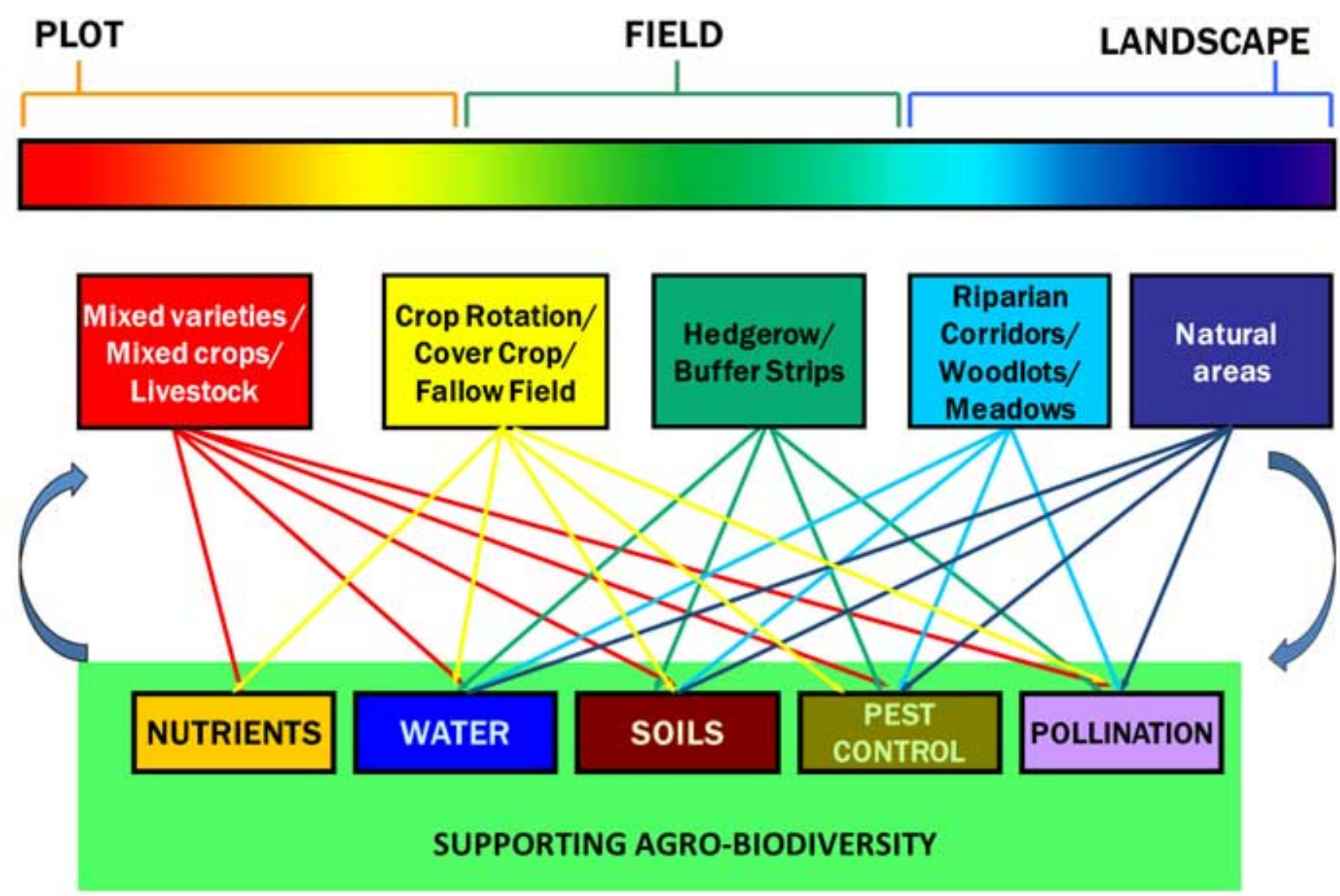

Across ecological scales, DFS practices include the use of: (Red, plot scale) multiple genetic varieties within a single crop or livestock species, or multiple species intercropped, including agroforestry, and/or integration of livestock, (yellow, field scale), crop rotations, covercropping/green manuring, or fallowing, all examples of practices that vary the planting in a given field over time, (green, field perimeter scale), planting of hedgerows or grassy buffer strips around crops, (light and dark blue, landscape scale), inclusion of woodlots, meadows, pastures, riparian corridors and other natural or semi-natural habitats in the cropped area. These practices lead to spatially heterogeneous farming systems, from plot to landscape scale, that intentionally include some aspects of biodiversity, while supporting others unintentionally. By supporting this "agrobiodiversity" (green box), these farming practices promote critical ecosystem services, such as nutrient and water cycling, soil formation, pest and disease control and pollination, as designated by the lines joining each farming practice to each service. Across temporal scales, these farming practices plus the natural successional processes enhance agrobiodiversity and ecosystem services dynamically.

provision far-away supermarkets and food processors, rather than subsistence and local markets (Watts and Little 1994, Goodman and Watts 1997, Clapp and Fuchs 2009). They may not have incentives or autonomy to experiment with alternative management practices and crops because of contractual agreements with food companies, lowest cost production pressures, government subsidy schemes and regulations, path-dependent processes driving toward specialization, and/or technological constraints (Goodman and Watts 1997). Collaboration among farmers across landscapes is usually seen as unnecessary, since food companies often provide powerful incentives (credit, processing facilities, seeds, technical assistance, and markets) that push individual farms to produce one crop variety in a specific way as part of a tightly integrated buyer-driven conventional supply chain (Roling and Wagemakers 1998, Raynolds 2004). Providing employment, livelihoods, and labor protections are far less important goals in industrialized production, since maximizing production and reducing labor costs are the priority. Thus, industrialized agriculture can play a role in declining rural employment and rural depopulation (Hazell and Woods 2008).

In industrialized agricultural systems, purposeful integration of beneficial biodiversity may be viewed as impeding production efficiency by competing for land and resources (Foley et al. 2005). 
Insectary strips, for example, reduce the cropped area and may hamper the planting and harvesting of monoculture fields. Industrialized systems also tend to treat complex environmental issues such as pests, weeds, livestock health, and soil fertility with one-off technological solutions, for example, through chemical inputs or genetically engineered crops. Because such solutions are often reductionist, they may engender additional problems, such as new and more virulent pests, pesticide accumulation in nontarget organisms, and pesticide-related public health impacts (Naylor and Ehrlich 1997, Letourneau and Bothwell 2008), such as increased levels of attention deficit disorder in children in farming communities (Marks et al. 2010). Industrialized agricultural systems often trade off short-term crop productivity for long-term ecological sustainability (Foley et al. 2005, Shennan 2008), for example, through substituting technologies for ecosystem services (i.e., replacement of natural regulation of pests with pesticides). In contrast, as a system that relies primarily on internal regeneration of critical inputs or ecosystem services (Figure 1), DFS must utilize holistic (systemsoriented) rather than reductionist approaches to succeed (e.g., Barberi 2002). For example, diversified farms cannot trade off production efficiency against maintenance of an essential service such as soil fertility, if soil fertility is to be generated from within the system.

\section{Box 2:}

DFS versus sustainable, organic, multifunctional and ecoagriculture While the concept of diversified farming systems shares much in common with multifunctional, organic, and sustainable and eco agriculture, it differs from each of these concepts in at least one subtle but fundamental way. Unlike any of these other concepts, the premise of DFS is that, through farming practices designed to support functional biodiversity across spatial and temporal scales, the necessary ecosystem properties providing critical inputs (services) to agriculture are supplied (Figure 1). While DFS generally exemplify the characteristics of multifunctional, organic, sustainable, or ecoagriculture, the reverse may not always be true.

Specifically, the practices of DFS are the same as those utilized in sustainable agriculture or agriculture that equitably balances concerns of environmental soundness, economic viability, and social justice within communities, across societies and into future generations (Allen and Sachs 1991, Kloppenburg et al. 2000). DFS should itself be ecologically sustainable because the farming practices that create a DFS maintain the underlying functional biodiversity that generates critical ecosystem services. However, a given farm can practice sustainable agriculture without being part of a DFS if situated within a homogeneous landscape that cannot provide ecosystem services that operate over larger scales, such as pest control or pollination (Tscharntke et al. 2005). In turn, a farm or landscape can use DFS strategies to increase ecological sustainability, but may not support social sustainability due to a lack of the institutions, attitudes, and actions that address these issues of justice and equity (Alkon and Agyeman 2011, Allen 2010).

In principle, DFS should not require the use of pesticides or inorganic fertilizers and thus meets the definition of organic. However, the converse is not always true: organic agriculture is now often practiced in large-scale monocultures (Figure 2) that may do little to foster biodiversity or sustain ecosystem services. While multifunctional agriculture (MFA) aims at producing multiple amenities (e.g., food, biofuels, recreation, scenery) from a farm or landscape, thus requiring some degree of crop, tree, livestock, or fish diversification, MFA does not always utilize agroecological approaches that support biodiversity and regenerate ecosystem services (Kleijn et al. 2006, Stoate et al. 2009). Merely diversifying crops and livestock may not necessarily create the multiscalar, multitemporal ecological heterogeneity and biotic interactions that would support the full suite of ecosystem services needed to support productive agriculture (Figure 1, see also Zhang et al. 2007, Shennan 2008).

DFS is similar to another concept, ecoagriculture, in recognizing that landscapes, not single farms, are important targets of land management. Other concepts, such as climate-smart agricultural landscapes or integrated watershed management, also make this link (http://blog.ecoagriculture.org/2012/03/05/terminology/, accessed Mar 13 2012), each with their own particular emphasis. DFS emphasizes how farming practices operating from plot to landscape scales maintain functional biodiversity and thus ecosystem services. Ecoagriculture emphasizes "landscapes in which biodiversity conservation is an explicit objective of agriculture" (Scherr and McNeely 2008:477). The DFS concept highlights the critical reciprocity underlying the ecoagriculture concept, that is, that the ecoagricultural landscape promotes biodiversity and in turn, critical components of biodiversity (i.e., functional biodiversity) promote agriculture through provision of ecosystem services. In summary, DFS, while closely allied to all of these concepts, places more emphasis upon the relationship between functional biodiversity and ecosystem services.

Fig. 2. Organic broccoli production as a monoculture in the Salinas Valley, California. Unlike a diversified farming system (whether certified as organic or not), this organic production system is more like conventional industrialized agriculture, utilizing substantial off-farm inputs such as purchased compost and other soil amendments, "organic" pesticides, etc. Photo by Rebecca Chaplin-Kramer.

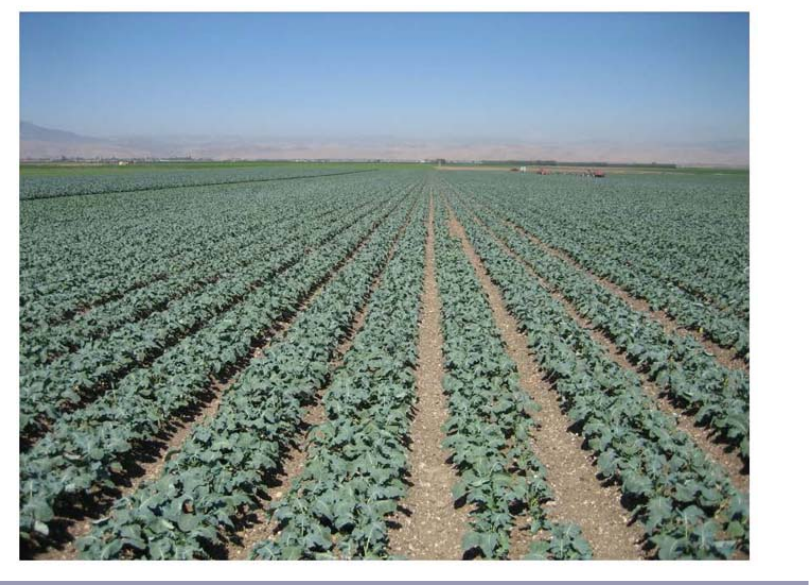




\section{DFS AS SOCIAL-ECOLOGICAL SYSTEMS}

DFS are complex social-ecological systems that enable ecological diversification through the social institutions, practices, and governance processes that collectively manage food production and biodiversity (Pretty 1995, Pretty 2003). As many political ecology scholars emphasize, ecosystems are densely interconnected with social relationships (Robbins et al. 2010). Ecological variables such as soil, water, and habitat help configure an array of farming practices, exchanges of food and resources, and landscape management decisions that, in turn, influence the structure and function of the ecosystem. Further, as ecosystem services are generated and regenerated within a DFS, the resulting social benefits (including a range of livelihood benefits, such as healthier diets and increased farmer autonomy) in turn support the maintenance of the DFS, enhancing its ability to provision these services sustainably (Bacon et al. 2012). This interplay underlies numerous historically occurring and emerging DFS worldwide. Conversely, socio-political and economic processes such as the decrease of access and control over seeds (often associated with the expansion of crop biotechnology) or increased dependence on commodity markets can intervene to disrupt such feedback cycles, thus weakening DFS. The industrialization of agriculture has led to growing homogeneity across food systems as farming techniques and markets become more standardized (Beus and Dunlop 1990, Lyson 2004). As a consequence, the complex social relationships underlying agriculture and ecosystem service provision have become less visible. Focusing on DFS can help farming communities, researchers, policy makers, and industry recognize and restore these relationships.

At their core, DFS depend on agroecological principles that are developed in and through the social relationships among working farmers, their communities and environments, and researchers, including ecologists, anthropologists, agronomists, and ethnobiologists (Wezel et al. 2009). As seen in the Kreman et al. (2012) examples these principles take varied forms depending on local conditions. To understand how DFS may develop, function, and evolve over time and space, the particular context of each DFS needs to be studied, paying particular attention to the politics and power relations that reciprocally shape its ecological conditions. Many DFS were developed through traditional and indigenous farming knowledge and agrobiodiversity that was accumulated over millennia (e.g., the milpa landscape in Mesoamerica; Xolocotzi 1985). More recently, other DFS have been created through targeted agroecological studies designed by scientists to solve particular problems (e.g., the push-pull system for maize agriculture in Kenya; Khan et al. 2011). Historically, much knowledge about biologically diverse farming practices has been created and shared through peer-to-peer learning within traditional farming communities and, more recently, also through their collaboration with researchers interested in further developing agroecology (Holt-Giménez 2006). These relationships continue to be critical to the growth of DFS in new societal contexts and geographic locations. Since the 1980s, with the rise of the Campesino-a-Campesino and La Via Campesina movements, institutions such as government agencies, domestic and international NGOs, and universities have become increasingly active in promoting and diffusing agroecological principles through research networks and programs (e.g., in Cuba; Rosset et al. 2011). These actors have added new institutional dimensions to the social relationships that help sustain DFS.

An illustration of how social and ecological systems interpenetrate within DFS is in the Andean highlands, where indigenous farmers have managed their lands agroecologically for 3,000 years (Brush 1982). The ongoing interplay between human management and physical ecology has created a landscape of agroclimatic belts at different altitudes, each characterized by specific field rotation practices, terraces, and irrigation systems, and the selection of specific animals, crops, and crop varieties (Altieri and Toledo 2011). Within these belts, traditional knowledge has helped sustain tremendous genetic diversity, by perpetuating adapted landraces and wild relatives of crops. Social cooperation is essential to managing the verticality and heterogeneity of the Andean ecosystem. A barter economy based on reciprocity, for example, facilitated complementary exchanges of plants and animals between ecological zones along the steep elevation gradient (Box 3).

\section{Box 3:}

The Andean highlands.

Several Andean cultures, including the Inca, adopted a political economy known as the ayllu system (Argumedo 2008). Each ayllu was an independent group with three levels of administration: the family, multiple families in a shared territory, and multiple territories in a larger organizing unit. Land was owned and managed collectively, with an assembly of farmers coordinating crop production in active fields while fallow spaces were used for livestock grazing. Thus, landscape ecology helped define a social system of nucleated settlements, communal landholdings, and land redistribution that reinforced the health of the ecosystem, a balance reflecting the Andean principles of reciprocity, duality, and equilibrium (Godoy 1994).

On the Bolivian and Peruvian altiplano, entwined systems of social and ecological diversity still thrive. For example, forty kilometers outside of Cuzco, Peru, a group of six communities have organized themselves into an agroecological farming collective known as Parque de la Papa ("Potato Park"). Socio-politically, they are attempting to reinvigorate the principles of the ayllu, with collective ownership of farmland, waters, pasture, and woodlands, and systems of cooperative labor (Agumedo 2008, also see, http://satoyamainitiative.org/en/case studies-2/area americas-2/the-ayllu-system-ofthe-potato-park-cusco-peru/, accessed May 30, 2012). These communities feed and clothe themselves and also generate new livelihoods from tourism, seeds, and medicinal plants that in turn 
enable them to maintain ecosystem services by being able to implement DFS practices when many workers could otherwise be forced to migrate to urban centers. They have made a precedent setting agreement with the International Potato Center, a CGIAR (Consultative Group on Agricultural Research) research institute based in Lima, Peru, to repatriate its seed collection for in situ cultivation in the Potato Park. ANDES, the local NGO supporting their efforts, envisages this park as the first step in building an Andean food sovereignty zone.

In industrialized systems in both developed and developing countries, farmers must now negotiate with corporate food buyers, buy agrochemical and seed inputs from agents, seek loans from bank officials, and work with agricultural extension experts trained in pesticide use. Farmers rely on such relationships to compete effectively in supply chains and to manage changing ecological conditions, such as pest outbreaks. Nonetheless, these particular types of relationships often push individual farms to increased dependence on banks, damaging livelihoods, and undermining collaborative social learning groups as farmers specialize in a single crop and maximize short-term yields through the use of external inputs, to meet loan repayments. The economic pressures in these tightly linked systems generally corrode ecosystem services, which are the very foundation of support for potential DFS. Farmers in industrialized systems may also engage in exploitative relations with immigrant or impoverished laborers, paying inadequate wages and enforcing long hours, helping perpetuate the apparent cheapness of food.

Industrial production creates a number of "distances" between producers and consumers (geographical, temporal, or cultural) such that information flow diminishes across the supply chain (Princen 2001). Thus within the industrial agri-food system, consumers remain relatively ignorant about the conditions of production, and would be less able to choose between products based on sustainability criteria, if they value these, and to exercise their buying power in favor of DFS. In turn, the risk perceptions of consumers and corporations may inhibit the growth of DFS. For example, during the recent food safety scare in fresh leafy vegetables in California, corporate buyers insisted that growers remove native vegetation bordering fields that might attract wildlife. This action was taken largely to assuage consumer concerns, despite the lack of scientific support (Beretti and Stuart 2008).

In alternative agricultural systems such as organic or low-input farming, farmers can build particular forms of relationships that help sustain ecosystem services and social infrastructure more effectively. We discuss many of these relationships, including direct marketing, fair trade certification, and food justice movements. In developing and studying these alternative systems, however, researchers, policy makers, and NGOs often neglect race, socioeconomic, and gender issues, or sublimate them into a broad social justice category. Finding ways to be far more inclusive of diverse racial, gender, and socioeconomic groups can help strengthen the socialecological basis of agriculture.

For instance, African-American growers once represented a sizable proportion of the U. S. farmer population, or one million in 1910 , declining to 18,400 by 1997 , due to race discrimination and violence, lack of land tenure (due to sharecropping practices), and multiple waves of economic migration from the South to urban centers (Reynolds 2002). Many of these black farmers used DFS practices; their displacement helped create an opening for industrialized monocultures. Now, many new farmers in rural and urban areas are black, Latino, or Asian; there is evidence that these farmers are more likely than their established peers to embrace sustainable agriculture practices if adequately supported (National Academy of Sciences 2010). Immigrants such as the Hmong may sometimes develop culturally relevant, more diversified food production enclaves within industrialized systems that preserve their traditions and provide livelihoods (Brown and Getz 2011). African-American groups have sought to reclaim and remold their rich heritage through urban farming. They are developing new linkages between cities and nearby rural areas, potentially helping recreate DFS. For example, Will Allen founded Growing Power, an urban farming NGO that serves disadvantaged neighborhoods in Milwaukee and Chicago, attempting to encourage youth of all races to take up diversified farming. In Chicago, black activists and physicians have formed the Healthy Food Hub, a food aggregation NGO which sources produce from a historically black farming community, Pembroke Township, about an hour from Chicago. These efforts show how people can demand greater political agency in building a democratic DFS (Bacon et al. 2012).

New quantitative and qualitative research is badly needed to evaluate and critique the social benefits that DFS may provide in contrast to industrialized systems. In general, further analysis is needed to understand how the social elements of DFS can help generate and regenerate ecosystem services, thus maintaining diversified farming systems. In turn, more research is required on the political and socioeconomic interventions that could help rebuild or sustain the socialecological cycles that underlie DFS.

\section{ALTERNATIVE AGRI-FOOD NETWORKS, FOOD SOVEREIGNTY AND JUSTICE}

DFS are often embedded in social, political, and economic conditions that differ from those accompanying industrialized monocultures (Box 1), particularly with respect to core stakeholders, markets, and distribution systems. Yet, DFS may not always be able to realize their potential social-ecological benefits due to the lack of enabling environments. We explore how alternative agri-food networks (AAFN) and social 
movements relate to DFS and assess their potential to both maximize social benefits and promote DFS through their demands for food sovereignty and food justice.

The agri-food systems approach reveals the interconnected systems of inputs, labor, land, capital, governance and knowledge that maintain specific types of agricultural production, distribution, and consumption systems (Friedland 2001). The governance and structure of the food system upstream from the farm, such as international agricultural trade liberalization policies that promote cheap food imports from industrial into developing countries, government subsidies for fossil fuel-based agrochemicals and commodity crops (Pimentel et al. 2008, Holt-Giménez and Patel 2009, Wise 2011) and irrigation projects that primarily benefit larger landholders (Frampton 1979, Walker 2004), all help to maintain the industrialized agri-food system (Clapp and Fuchs 2009, Gottlieb and Joshi 2010). This system then creates substantial obstacles to farmers seeking to use diversified farming methods, generate value from ecosystem services, and sell food products to viable markets. It also leaves consumers and communities disconnected from the origins, qualities, and the social and ecological consequences of the production of their food, fuel, and fiber.

In the same way that industrialized monoculture production systems are sustained by industrialized agri-food systems, diversified farming systems are frequently interdependent with alternative agri-food networks (AAFNs) (Goodman and Watts 1997). AAFNs work "against the logic of bulk [high volume, low cost] commodity production, alternative food networks redistribute value through the food chain, reconvene 'trust' between producers and consumers, and articulate new forms of political association and market governance" (Whatmore et al. 2003:289). They are often, but not always, rooted in agroecological farming practices (Kloppenburg et al. 2000, Gliessman 2007).

AAFNs regularly use the trust and engagement generated through alternative forms of distribution to increase access to healthy, fresh, and diverse foods among consumers while providing farmers with diverse revenue streams, and risksharing and direct marketing strategies that cut the costs of distribution and decrease reliance on industrialized agri-food systems. AAFNs generally emerge as partnerships connecting DFS farmers with citizens, consumers, governments, food and agricultural enterprises, and environmental and social justice organizations through the development of various institutions ranging from farmers' markets, urban gardens, and community-supported agriculture at local and regional scales, to fair trade producer cooperatives, slow food movements, and peasant organizations at the global scale (Goodman et al. 2011). These partnerships represent a new wave of social activism as Northern and Southern communities and NGOs increasingly focus on the politics and cultures of food, and identify economic incentives to transform industrialized agrifood into alternative systems that seek to produce and distribute healthy, environmentally sustainable, and socially just food.

The equitable treatment of producers is central to achieving broader adoption of DFS. If farmers are impoverished or are forced to compete with subsidized producers or importers from the industrialized food system, they are less likely to sustain diversified farming practices. Farmers markets are one example of efforts that more equitably support small-scale producers, as well as urban consumers. The estimated 7525 farmer markets in the U.S. offer local civic outlets that may generate social, economic, and cultural incentives for DFS among local farmers while encouraging a more diverse diet of fresh foods among eaters (Lyson 2004, United States Department of Agriculture 2011a, Zezima 2011). Farmers markets can provide a mechanism for farmers to reach consumers directly, educate them about DFS practices, and bypass the processing and distribution infrastructure of the industrialized agri-food systems. Yet, while farmers markets and other AAFNs may help develop and maintain DFS and vice versa, they do not yet adequately recognize ecological diversification and sustainability as core values. Farmers markets often provide a venue for organic agriculture, but they rarely use ecological sustainability as a criterion for allowing producer participation, and such markets may also include organic foods harvested from industrial monoculture (Payne 2002). In addition, while farmers markets may improve equity for smaller scale growers, they may not provide equity for consumers. Although recent policies have sought to address these challenges, less than $20 \%$ of farmers markets accepted food assistance vouchers in 2009 (Haering and Syed 2009). Farmers markets may not reach poorer socioeconomic groups, due to both price and location. Efforts are underway to increase the number of farmers markets accepting government food assistance vouchers (Zezima 2009).

In Northern countries, environmental justice advocates have recently started to promote sustainable agriculture and/or agroecology as part of a multipronged, holistic strategy for pursuing food and environmental justice across the entire production chain to remedy the environmental inequalities associated with industrialized agricultural systems (Gottlieb and Joshi 2010, Wittman et al. 2010, Alkon and Agyeman 2011). These inequalities can be traced back to how, under what conditions, and by whom food is produced, processed, distributed, and consumed, and the role of corporations and governments in shaping these conditions. Food justice issues include the unfair treatment of workers in housing, health, and labor conditions (Shreck et al. 2006, Getz et al. 2008); agrochemical exposure health risks to workers, communities, and consumers (Pulido and Peña 1998, Galt 2008, Marks et al. 2010, Harrison 2011, Peña 2011); loss of ecosystem services such as water and soil (Diaz et al. 2006, Corbera et 
al. 2007); creation of pollution/wastes that affect surrounding communities (Osterberg and Wallinga 2004); lack of farm and food worker access to healthy foods (Wirth et al. 2007); and loss of access to land (Wolford 2008). By addressing these issues, food justice activism is evolving toward a strategy that encompasses both social justice and ecological sustainability (Gottlieb and Joshi 2010).

These local and national efforts are complemented by several international projects to create AAFNs and connect them to sustainable agriculture. One example is the global fair trade movement, which aims to enable consumers, often in developed countries, to pay more equitable prices to cover the full costs of production and ensure sustainable farmer livelihoods. Fair trade is not synonymous with DFS or sustainable agriculture because its criteria focus primarily on the social and economic aspects of trade and production. However, the Mesoamerican smallholders who cofounded this movement with political and religious activists manage agricultural systems that are far closer to DFS than industrial monocultures (Bacon et al. 2008, VanderHoff Boersma 2009). Their shade coffee systems now often resemble native forests and help conserve biodiversity, reduce soil erosion, conserve water, improve microclimates and resist hurricane damage (Perfecto et al. 1996, Lin 2007, Philpott et al. 2008a, b, Mendez et al. 2010). Farmers' connections to smallholder cooperatives and global fair trade networks also partially mitigated vulnerability to crashing coffee commodity prices (Bacon et al. 2008).

New social movements also increasingly promote agroecology as central to their agenda for transforming the industrialized agri-food system at local, national, and global scales (Sevilla Guzmán 2006, Wolford 2008). In particular, a food sovereignty agenda has emerged from the aspirations and survival needs of smallholders and indigenous social movement leaders in the Global South (Windfuhr and Jonsen 2005, Rosset 2008). Food sovereignty (La Via Campesina 2009) refers to the right of local peoples to control their own agricultural and food systems, including markets, resources, food cultures, and production modes, in the face of an increasingly globalized economic system. This approach contrasts with charity-based food security models that have occasionally buffered human populations from famines (Kaluski et al. 2002), yet do not address root causes of hunger and care little for how, where, and by whom food is produced (Wittman 2009, Wittman et al. 2010). It also contrasts with dominant neoclassical trade liberalization policies that open up domestic markets worldwide to competition from multinational corporations, which has often resulted in import dumping, the erosion of smallholder livelihoods, and greater industrialization of agriculture (McMichael 2009). Food sovereignty movements promote agrarian reforms, resist state and corporate land grabs, and critique proposals that contribute to farmer debt and dependence (Wittman et al. 2010). In recent decades, the food sovereignty movement has endorsed the agroecological approaches and the social process methodologies promoted through the Campesino- $a$ Campesino movement (Holt-Giménez 2006).

Despite the potential of AAFNs such as farmers markets and fair trade networks to sustain and promote DFS, many alternative agri-food activities have come to resemble the industrialized agri-food systems they set out to transform. For example, the dramatic growth in organic sales in the past two decades facilitated by product certification has promoted the expansion of large-scale industrialized organic monocultures to supply this new demand (Guthman 2004, Bacon et al. 2012, see also Figure 2) even though the founding principles of organic agriculture included DFS practices (Box 2). Alternative producers sometimes justify this by arguing that large-scale, industrialized methods are the fastest way to "scale up" alternative farming practices so that they can compete in supply chains with conventionally managed systems (Box 4). In search of new markets, many dominant food corporations have purchased and integrated successful organic producers and alternative food companies into their product portfolios (Kearins and Collins 2012). This trend of purchasing "sustainable" product businesses is also observed in other sectors, such as personal care, paper, and cleaning chemicals. A growing body of literature on green consumerism raises the issue of corporate "greenwashing". Researchers suggest that expanding corporate control over alternative products can generate some benefits (e.g., reduced pesticide usage, cleaner production practices, and investments in social development). Yet these changes may accelerate efforts to industrialize production rather than expand alternative systems (Goodman and Watts 1997). These developments call for careful scrutiny of the changing standards, price premiums, ingredients, farm level practices, and benefits to producers and consumers (Bacon et al. 2008, Clapp and Fuchs 2009).

\section{Box 4:}

Scaling up DFS and AAFN supply chains

The issues of scale and scaling up are central in shaping the development of DFS, certification, and AAFN-driven supply chains (Sayre 2005). Scale refers to the size of a given farming operation, whereas scaling up refers to the expansion of a farming practice in the agricultural system as a whole. There is growing debate regarding the means of expanding agroecological practices across the agricultural system. Some researchers, many firms, and policy makers argue that agri-food businesses will inevitably dominate alternative farming because they can implement alternative practices at high levels of productivity more effectively than food movements and smallholder farmers (Burch and Lawrence 2005). In contrast, other research suggests that, in both developed and developing countries, smaller farms are more productive in comparison to larger operations, in part because they employ DFS practices (Netting 1993, Rosset 1999). This effect may occur because farmers can exploit every ecological niche in their diversified farms to achieve greater 
productivity, whereas farmers on large-scale landholdings may lack this knowledge intensive ability (Altieri 2002, Gliessman 2007). Indeed, it remains unclear whether larger scale farms (e.g., farms exceeding $\$ 250,000$ in sales in the U.S.) are even able to carry out the ecological diversification that smaller farms have been able to achieve while retaining high levels of productivity. Mechanization associated with modern large-scale operations, for example, may undermine ecosystem services.

In principle, large landholdings, whether individuals, cooperative groups, nucleated settlements, or common property regimes, are better placed to implement DFS because of their resources and ability to control, or coordinate across, a larger portion of the landscape. They could include multiple components such as pasturelands, row crops, orchards, and natural habitats within their own lands. In turn, when a larger proportion of the landscape is managed with agroecological practices, all growers can benefit from the enhanced ecosystem services that are produced, such as pest control and crop pollination services (Gabriel et al. 2010, Kremen and Miles 2012). Conversely, the bigger an individual farm is, the more vulnerable it could be to being co-opted into the industrial organic system and into corporate ownership because of pressures to achieve greater economic returns.

Whether large (as well as small) landholdings are able to practice DFS may depend on farmers' power to manage their lands, which reflects the pattern of ownership rights, farming styles, economic pressures, and farmer autonomy existing in a particular region. Various types of ownership, including farmer cooperatives, family companies, communal institutions, and absentee businesses, may be more or less supportive of DFS at different scales. Individual tenants, for example, may be less willing to implement DFS where absentee landlords lack interest in ecological sustainability, or are subjecting them to economic pressures (e.g., rent demands or debt repayment) that discourage DFS practices. In turn, different patterns of ownership could enable small-scale management across large landholdings that can provide ecosystem benefits equivalent to smallholdings. One example is the Baix Llobregat Agricultural Park near Barcelona, where an Agricultural Park Consortium comprising local and regional governments manages a mosaic of landholdings (Bacon et al. 2012). Further research is therefore needed to understand how DFS performance may vary with scale, and whether scaling up can only follow a pathway akin to industrialized agriculture, or can be achieved through giving greater power to diverse forms of management and landholdings across large regions.

In parallel, fair trade labeling organizations initially certified exports from smallholder organizations only, thus frequently supporting DFS. However, recent changes to standards now allow transnational agricultural trade companies to export certified Fair Trade products in direct and potentially unfair competition with the smallholder organizations that this system intended to empower (Bacon 2010, Jaffee and Howard 2010). The dominant U.S. Fair Trade certification agency has ignored strong protests from smallholder farmer organizations in recently allowing large coffee plantations to sell certified Fair Trade coffee. For instance, a growing portion of Fair Trade certified coffee sold in the U.S. now originates in Brazil and Colombia in production systems supporting fewer and less diverse shade trees than Mesoamerican smallholders (Jha et al. 2011).

In this light, many enterprises and organizations within the rapidly mainstreaming AAFNs are now trying to restrengthen their connections to sustainable agriculture and their original social goals through innovative organizational reforms. They are de-emphasizing the certification systems that they once pioneered and moving toward food sovereignty and food justice that promote the power of participants to control or coordinate their parts of the larger food system. These trends could enable the spread of DFS while simultaneously promoting the often overlooked social equity and participatory process dimensions of sustainable agriculture (Allen and Sachs 1991, Alkon and Agyeman 2011, Bacon et al. 2012). However, until recently, these movements have represented relatively small countertrends compared to the dominant certified and organic components of the industrialized agrifood system.

Certifications and market-based incentives could (and likely will) be an important component of many DFS oriented transition processes. However, broader institutional support is certainly needed. Furthermore, the leading sustainability certifications increasingly do not appear to reward the diverse forms of ownership, management, and local collaboration that would be needed to ensure the landscape-scale nature of DFS, and their standards have become increasingly flexible (and lower in some aspects) as they increasingly include industrial production systems (Jaffee and Howard 2010).

\section{GLOBAL TRENDS IN AGRICULTURE}

\section{Industrialized agriculture}

The expansion of large-scale industrialized monoculture systems of agriculture often occurs at the expense of more diversified farming systems. The widespread transformation of agriculture to large-scale monoculture systems began with the European colonial plantations of the 1500-1800s (McMichael 2009, Perfecto et al. 2009), and expanded with the mechanization of agriculture in the late 1800s and the introduction of synthetic fertilizers and pesticides by the mid $20^{\text {th }}$ century. By the 1960 s, a wave of agricultural science and technological innovations had created the "Green Revolution," an integrated system of pesticides, chemical fertilizers, and genetically uniform and high-yielding crop varieties that governments, companies, and foundations vigorously promoted around the world (Evenson and Gollin 2003, Smil 2004).

In the subsequent fifty years, the expansion of industrialized agriculture increased global nitrogen use eightfold, phosphorus use tri-fold, and global pesticide production eleven-fold (Tilman et al. 2001). By 2000, Green Revolution crop varieties were broadly adopted throughout the developing 
world, e.g., circa $90 \%$ of Latin America for the area under wheat, and circa $80 \%$ in Asia for the area under rice (Evenson and Gollin 2003), and the world's irrigated cropland doubled in area (Tilman et al. 2001). Encouraged by a range of economic factors, including the incentives of U.S. federal commodity programs, the pressures of global market competition, neoliberal economic reforms, historically inexpensive synthetic inputs, and the advantages of economies of scale, field and farm sizes increased in some areas, while noncrop areas in and around farms decreased, leading to higher levels of homogeneity at both the field and landscape scale (Cochrane 1993, Tscharntke et al. 2005, Liverman and Vilas 2006, Snapp et al. 2010).

Several recent signs of the continued expansion of industrial agriculture are seen in the rapid growth of land grabs, biofuel production, and plantations across the Global South. Land grabbing refers to the practice of agri-food companies, commodity traders, pension funds, and nationally-owned investment banks buying land in other countries for eventual large-scale food and resource production in response to food security concerns and food speculation (McMichael 2010, Borras et al. 2011, de Schutter 2011). For example, the provincial government of Rio Negro in Argentina recently agreed to lease up to 320,000 ha of land to Beidahuang, a Chinese government-owned agri-food company, to produce soybeans, wheat, and oilseed rape primarily for animal feed (GRAIN 2011). Negotiations occurred in secret and the agreement was signed before it became public. Local farming communities are now organizing against the deal, contending that they will be displaced by the industrialized irrigation methods being planned.

Estimates of the global scale of land grabbing are scarce and largely based on media reports. Whereas the International Food Policy Research Institute estimates that 20 million ha of land were sold for land grabs between 2005 and 2009, the World Bank calculates that around 57 million ha have attracted foreign interest (Von Braun and Meinzen-Dick 2009, Deininger 2011).

The expansion of large-scale commercial agriculture has also caused deforestation of some of the most biodiverse forests in the world, such as in the Amazon, for soybean production (Defries et al. 2008), and in Southeast Asian rain forests, for oil palm (Wilcove and Koh 2010). Since the 1990s, particularly in Brazil and Indonesia where the greatest amount of deforestation occurred, the agents of deforestation shifted from primarily smallholder to enterprise-driven agriculture for global markets (Rudel et al. 2009, De Fries et al. 2010). Much recent forest loss, along with agricultural land conversion, can be attributed to the rapid growth in biofuel production, centering in Southeast Asia and Latin America but expanding to Africa. Biofuel production is driven by mandates for renewable transport fuels, weak land use regulation, production subsidies, and speculation by energy and commodity companies in both developing and industrial countries (Borras et al. 2011).

Although global estimates of the scale of industrial biofuel production are difficult to make, the World Bank (Deininger 2011) calculates that 36 million ha were dedicated to biofuel production (primarily maize, sugar cane, and oil crops) globally in 2008, doubling the 2004 level. Oil palm production in Indonesia and Malaysia indicates the emerging trajectory: aided by government policies and subsidies, oil palm plantations grew in Indonesia from 3.6 million ha in 1961 to 8.1 million ha by 2009 (McMichael 2010). The consequences of the expansion of oil palm include ongoing displacement of smallholders, increasing monoculture, and abandonment of food cropping, though the extent to which these effects are occurring remains uncertain (Dauvergne and Neville 2010, Li 2011). Across the Global South, oil palm and sugarcane plantations may provide only a tenth of the jobs when compared to the livelihoods generated through smallholder farming (Holt-Giménez 2007).

\section{Smallholder agriculture}

Despite expansion of large-scale commercial agriculture, smallholders $(<2$ ha) still make up $85 \%$ of circa 525 million farms worldwide (Nagayets 2005). Such farmers span a spectrum from traditional, indigenous growers using no external inputs to those with heavy dependency on modern seed varieties, fertilizers, and pesticides, but up to $50 \%$ of smallholders are thought to utilize resource conserving farming methods (Altieri and Toledo 2011). While they represent the bulk of the agricultural population, estimated at circa 2.6 billion people (Dixon et al. 2001), due to land inequalities they often do not control the bulk of the arable land (Nagayets 2005). These disparities are largest in South America, (e.g., in Ecuador, smallholders constitute $43 \%$ of the farmers but use only $2 \%$ of the land) and least pronounced in Africa (e.g., in Egypt, smallholders constitute $75 \%$ of the farmers and use $<50 \%$ of the land). Another sign of intensifying inequalities is that mean farm size has decreased in many parts of Africa and Asia (e.g., from 2.3 to 1.6 ha from 1970 to 1990 in India), increasing the vulnerability of small farmers and exacerbating the poverty in these regions, while large landholdings are increasingly controlled by a small number of people (Nagayets 2005).

Despite poverty, the current contribution of small farms to global food production is significant. Herrero et al. (2010) estimate that mixed crop and livestock systems supply $50 \%$ of the worlds' cereal, $60 \%$ of the world's meat and $75 \%$ of the world's dairy production. Much of this production is locally produced and consumed, and provides the main source of food for the world's 1 billion poor (defined as living on $<\$ 1 /$ day). Altieri (2004) considers that traditional indigenous agriculture supplies $30-50 \%$ of the world's food. Nagayets (2005) 
suggests that the contribution of smallholders to food production is increasing in some countries because of changing national socioeconomic and political situations and government policies favoring domestic food self-sufficiency (e.g., Cuba). As indicated previously, not all smallholder agriculture would be considered DFS. Perhaps $50 \%$ of smallholder farmers use agro-industrial inputs or have not adopted agroecological methods (Altieri and Toledo 2011). Qualitative research suggests that through implementation of "sustainable intensification", a set of resource conserving practices also used in DFS (Netting 1993, Pretty et al. 2006), such farms could become 60-100\% more productive, potentially contributing far more to local and global food security (Pretty et al. 2006, Badgley et al. 2007), although rigorous, quantitative comparisons are both lacking and needed (Seufert et al. 2012).

Overall, small-scale diversified farmers face continuous, intensifying pressures from the encroachment of industrial supply chains (Holt-Giménez 2006). However, in parts of the developing world, diversified farming systems are actually expanding, in response to food sovereignty movements, smallholder desires for healthier and more economically independent lives, and some level of civil society and government support. Agroecological techniques are sitespecific and tend to be transferred from location to location through horizontal communication and social networks, with much adaptation by local communities (Holt-Giménez 2006, Altieri and Toledo 2011). Evidence of the rising adoption of agroecological principles in many Latin and Central American countries exist through the many cases of campesino-tocampesino training reported, as well as the increasingly global spread of the La Via Campesina movement (Holt-Giménez 2006, Wittman et al. 2010, Altieri and Toledo 2011). Cuba is a case where the transition to agroecological practices has been particularly rapid (from 200 families in 1999 to 110,000 families by 2009 by some estimates); in this case the expansion was a response to a severe food security crisis and lack of fossil fuel inputs following collapse of the former USSR and associated subsidies to industrialized agriculture (Rosset et al. 2011).

To some degree, DFS are also expanding in industrial countries despite the vastly more inhospitable political and economic conditions that may prevail, particularly in the U.S. There, as in Australia and many European countries, there is growing demand for organic and locally produced fruits, vegetables, fish, and meat, which is spawning an increase in the number of small-scale, highly diverse farms, often supplying urban markets (Kristiansen et al. 2006, Pollan 2006). In the U.S., certified organic agriculture has grown markedly, rising from less than 1 million acres in 1990 to 4.8 million acres in 2008 (of which $56 \%$ is croplands and the remainder rangelands) and comprises $0.7 \%$ of agricultural production with 20,000 producers (United States Department of Agriculture 2011b). Worldwide, organic agriculture has tripled from 11 million ha in 1999 to 37.2 million ha in 160 countries as of 2009 and currently makes up $0.9 \%$ of agricultural production (Willer and Kilcher 2011), with 1.8 million producers in 2009, predominantly from Asia and Africa. Nonetheless, while organic agriculture tends to support greater biodiversity than conventional farms (Bengstton et al. 2005), not all organic farms are DFS (Box 2, Figure 2). Much organic agriculture has become increasingly large-scale and homogeneous as producers and food companies strive to maximize profits and meet growing market demand (Guthman 2004).

\section{IN THIS SPECIAL FEATURE}

The series begins by examining what is known about how DFS maintain a range of ecosystem services that provide critical inputs to farming, including soil quality, water use efficiency, control of weeds, diseases and pests, pollination services, carbon sequestration, energy efficiency/greenhouse warming potential, resistance and resilience to climate change, food production, and biodiversity. By comparing DFS to conventional industrial systems, Kremen and Miles (2012) find that DFS significantly enhance all the ecosystem services measured with the exception of crop production, although not necessarily to the level required to control pests and diseases or provide sufficient pollination. The authors note that relatively few research dollars have yet been applied to the improvement of DFS compared to conventional systems; redressing this substantial inequality in public and private investment is necessary to close yield gaps while maintaining environmental benefits. The authors recommend that new research should be holistic and integrated across many components of the farming system to identify management systems that can take advantage of potential synergies.

Next, Bacon et al. (2012) seek to simultaneously deepen our understanding of the social consequences of DFS vs. industrial production and to unpack several key influences affecting continuity, change, and possibilities for transformation of these systems. Case studies from California's Central Valley, Mesoamerican coffee agroforestry systems, and agricultural parks in the European Union, identify the critical role of government policy in an agricultural system's emergence and the combination of market demand and multiactor governance that provide continuity. They find that the spread of DFS will generate social benefits, including decreased pesticide exposures, improved food security, longer agricultural working seasons, and healthier diets, but may also generate new costs, such as increased muscular skeletal injuries associated with higher manual labor demands. Social movements can alter governance arrangements and influence 
both the spread of DFS and the creation of policies that increase environmental benefits and reduce social costs. However, broader changes to the market and political structures and economic policies of agriculture are needed to enable a socially sustainable expansion of DFS.

Iles and Marsh (2012) consider several examples of obstacles to the adoption and spread of DFS in industrialized agricultural systems. These include the broader political economic context of industrialized agriculture, the erosion of farmer knowledge, and supply chain and marketing conditions that limit farmers' ability to adopt diversified practices. To overcome these obstacles and nurture DFS, policy makers can transform agricultural research, develop peer-to-peer learning processes, support recruitment of new farmers, invest in improved agricultural conservation programs, compensate for provision of ecosystem services in working landscapes, and develop direct links to consumers and institutional markets.

In contrast to analyzing a market-led expansion of DFS, Rosset and Martinez-Torrez (2012) propose a theoretical framework focused on disputed rural territories and repeasantization to understand how and why rural social movements have increasingly adopted agroecology and diversified farming systems as part of their discourse and practice. Rural spaces are increasingly disputed as agribusiness seeks to "grab land", control production systems, and remove many rural inhabitants from the land, while small-scale farmers, rural workers, indigenous communities and women are increasingly organized into social movements, such as Via Campesina, that seek to repopulate or maintain these landscapes through the defense of their food, seed, and land sovereignty. For peasants, family farmers and their social movements, agroecology helps both to build autonomy from unfavorable markets and to restore degraded soils. The social process of sharing these practices and values from farmer to farmer (Campesino- $a$ Campesino), coupled with broader global social movements, help bring alternatives such as DFS to scale.

We finish the series with an in-depth analyses of specific farming or social systems. Sayre et al. (2012) examine how ranching is the most ecologically sustainable segment of the U.S. meat industry and exemplifies many of the defining characteristics of DFS. Rangelands also provide other ecosystem services, including watershed functioning, wildlife habitat, recreation, and tourism. Innovations in marketing, incentives and easement programs that augment ranch income, creative land tenure arrangements, and collaborations among ranchers can support greater diversification. Taking advantage of rancher knowledge and stewardship can support the sustainability of ranching and its associated public benefits.

We have attempted to launch the concept of DFS by encouraging broad based interdisciplinary collaboration and practice from the outset, through combining our analysis of the ecology of food production with complementary questions of food access, distribution, and structure of the agri-food systems. This special feature thus incorporates insights from ecology, economics, political economy, and related social science fields to create a more inclusive analysis of the challenges and opportunities that influence efforts to achieve food security and the multiple dimensions of sustainable agriculture.

Responses to this article can be read online at: http://www.ecologyandsociety.org/issues/responses. $\mathrm{php} / 5103$

\section{Acknowledgments:}

We thank the members of the Diversified Farming Systems Working Group at University of California, Berkeley for many stimulating discussions and the Berkeley Institute of the Environment and the Neckowitz Family Foundation for supporting this effort, and the S.V. Ciriacy-Wantrup Postdoctoral Fellowship for initially bringing both Iles and Bacon to the University of California Berkeley. The work has benefited from comments provided by M. Altieri, L. Carlisle, M. Montenegro, P. Rosset, and an anonymous reviewer. All authors contributed equally to this article.

\section{LITERATURE CITED}

Alkon, A. H., and J. Agyeman. 2011. Cultivating food justice: race, class, and sustainability. MIT Press, Cambridge, MA, USA.

Allen, P. 2010. Realizing justice in local food systems. Cambridge Journal of Regions, Economy and Society 3 (2):295-308. http://dx.doi.org/10.1093/cjres/rsq015

Allen, P. L., and C. E. Sachs. 1991. The social side of sustainability: class, gender and race. Science as Culture 2 (4):569-590. http://dx.doi.org/10.1080/09505439109526328

Altieri, M. A. 2002. Agroecology: the science of natural resource management for poor farmers in marginal environments. Agriculture, Ecosystems \& Environment 93 (1-3):1-24. http://dx.doi.org/10.1016/S0167-8809(02)00085-3

Altieri, M. A. 2004. Linking ecologists and traditional farmers in the search for sustainable agriculture. Frontiers in Ecology and the Environment 2(1):35-42. http://dx.doi.org/10.1890/1540-9295 (2004)002[0035:LEATFI]2.0.CO;2

Altieri, M. A., and V. M. Toledo. 2011. The agroecological revolution in Latin America: rescuing nature, ensuring food sovereignty and empowering peasants. Journal of Peasant Studies 38(3):587-612. http://dx.doi.org/10.1080/03066150.2011.582947 
Argumedo, A. 2008. The Potato Park, Peru: conserving agrobiodiversity in an Andean Indigenous Biocultural Heritage Area, Pages 45-58 in T. Amend, J. Brown, A. Kothari A., A. Phillips, and S. Stolton, editors. Protected Landscapes and Agrobiodiversity Values. Volume 1 in the series, Protected Landscapes and Seascapes, International Union for the Conservation of Nature (IUCN) \& GTZ (Deutsche Gesellschaft für Technische Zusammenarbeit, Kasparek Verlag, Heidelberg, Germany.

Bacon, C. M. 2010. Who decides what is fair in fair trade? The agri-environmental governance of standards, access, and price. The Journal of Peasant Studies 37(1):111-147. http:// dx.doi.org/10.1080/03066150903498796

Bacon, C. M., V. E. Mendez, S. R. Gliessman, D. Goodman, and J. A. Fox. 2008. Confronting the coffee crisis: fair trade, sustainable livelihoods and ecosystems in Mexico and Central America. MIT Press, Cambridge, MA, USA.

Bacon, C. M., C. Getz, S. Kraus, M. Montenegro, and K. Holland. 2012. The social dimensions of sustainability and change in diversified farming systems. Ecology and Society 17(4): 41. http://dx.doi.org/10.5751/ES-05226-170441

Badgley, C., J. Moghtader, E. Quintero, E. Zakem, M. J. Chappell, K. Aviles-Vazquez, A. Samulon, and I. Perfecto. 2007. Organic agriculture and the global food supply. Renewable Agriculture and Food Systems 22(02):86-108. http://dx.doi.org/10.1017/S1742170507001640

Barberi, P. 2002. Weed management in organic agriculture: are we addressing the right issues? Weed Research 42 (3):177-193. http://dx.doi.org/10.1046/j.1365-3180.2002.00277. $\underline{\mathrm{x}}$

Bengtsson, J., J. Ahnstrom, and A. C. Weibull. 2005. The effects of organic agriculture on biodiversity and abundance: a meta-analysis. Journal of Applied Ecology 42:261-269. http://dx.doi.org/10.1111/j.1365-2664.2005.01005.x

Beretti, M., and D. Stuart. 2008. Food safety and environmental quality impose conflicting demands on Central Coast growers. California Agriculture 62(2):68-73. http://dx. doi.org/10.3733/ca.v062n02p68

Beus, C., and R. Dunlop. 1990. Conventional versus alternative agriculture: the paradigmatic roots of the debate. Rural Sociology 55(4):590-616. http://dx.doi.org/10.1111/ j.1549-0831.1990.tb00699.x

Borras, S., R. Hall, R., S. Scoones, B. White, and W. Wolford. 2011. Towards a better understanding of global land grabbing: an editorial introduction. Journal of Peasant Studies 38 (2):209-216. http://dx.doi.org/10.1080/03066150.2011.559005

Brown, S., and C. Getz. 2011. Farmworker food insecurity and the production of hunger in California. Pages 478-507 in A. Alkon, and J. Agyeman, editors. Cultivating food justice.
Race, class, and sustainability. MIT Press, Cambridge, MA, USA.

Brush, S. 1982. The natural and human environment of the Central Andes. Mountain Research and Development 2 (1):19-38. http://dx.doi.org/10.2307/3672931

Burch, D., and G. Lawrence. 2005. Supermarket own brands, supply chains and the transformation of the agri-food system. Journal of Sociology of Agriculture 13(1):1-28.

Childers, D., J. Corman, M. Edwards, and J. Elser. 2011. Sustainability challenges of phosphorus and food: solutions from closing the human phosphorus cycle. Bioscience 61 (2):117. http://dx.doi.org/10.1525/bio.2011.61.2.6

Clapp, J., and D. Fuchs. 2009. Corporate power in global agrifood governance. MIT Press, Cambridge, MA, USA.

Cochrane, W. W. 1993. The development of American agriculture: A historical analysis. University of Minnesota Press, Minneapolis, USA.

Corbera, E., N. Kosoy, and M. Martínez Tuna. 2007. Equity implications of marketing ecosystem services in protected areas and rural communities: case studies from MesoAmerica. Global Environmental Change 17(3-4):365-380. http://dx.doi.org/10.1016/j.gloenvcha.2006.12.005

Cribb, J. 2010. The coming famine: the global food crisis and what we can do to avoid it. University of California Press, Berkeley, CA, USA.

DeFries, R. S., D. C. Morton, G. R. van der Werf, L. Giglio, G. J. Collatz, J. T. Randerson, R. A. Houghton, P. K. Kasibhatla, and Y. Shimabukuro. 2008. Fire-related carbon emissions from land use transitions in southern Amazonia. Geophysical Research Letters 35(22). http://dx.doi. org/10.1029/2008GL035689

Dauvergne, P., and K. J. Neville. 2010. Forests, food, and fuel in the tropics: the uneven social and ecological consequences of the emerging political economy of biofuels. Journal of Peasant Studies 37(4):631-660. http://dx.doi.org/10.1080/03066150.2010 .512451

DeFries, R. S., T. Rudel, M. Uriarte, and M. Hansen. 2010. Deforestation driven by urban population growth and agricultural trade in the twenty-first century. Nature Geoscience 3(3):178-181. http://dx.doi.org/10.1038/ngeo756

Deininger, K. 2011. Challenges posed by the new wave of farmland investment. Journal of Peasant Studies 38 (2):217-247. http://dx.doi.org/10.1080/03066150.2011.559007

De Schutter, O. 2011. How not to think of land-grabbing: three critiques of large-scale investments in farmland. Journal of Peasant Studies 38(2):249-279. http://dx.doi.org/10.1080/03$\underline{066150.2011 .559008}$ 
Diaz, R. J., and R. Rosenberg. 2008. Spreading dead zones and consequences for marine ecosystems. Science 321 (5891):926-929. http://dx.doi.org/10.1126/science.1156401

Díaz, S., J. Fargione, F. Chapin, and D. Tilman. 2006. Biodiversity loss threatens human well-being. PLoSBiol 4 (8):277. http://dx.doi.org/10.1371/journal.pbio.0040277

Dixon, J., A. Gulliver, and D. Gibbon. 2001. Farming systems and poverty: improving farmers' livelihoods in a changing world. Food and Agriculture Organization (FAO), Rome, Italy, and Washington, D. C., USA.

Evenson, R. E., and D. Gollin. 2003. Assessing the impact of the Green Revolution, 1960 to 2000. Science 300(5620):758. http://dx.doi.org/10.1126/science.1078710

Foley, J., R. DeFries, G. Asner, C. Barford, G. Bonan, S. Carpenter, F. Chapin, M. Coe, G. Daily, H. Gibbs, J. Helkowski, T. Holloway, E. Howard, C. Kucharik, C. Monfreda, J. Patz, I. Prentice, N. Ramankutty, and P. Snyder. 2005. Global consequences of land use. Science 309 (5734):570-574. http://dx.doi.org/10.1126/science.1111772

Foley, J., N. Ramankutty, K. Brauman, E. Cassidy, J. Gerber, M. Johnston, N. Mueller, C. O'Connell, D. Ray, P. West, C. Balzer, E. Bennett, S. Carpenter, J. Hill, C. Monfreda, S. Polasky, J. Rockström, J. Sheehan, S. Siebert, D. Tilman, and D. Zaks. 2011. Solutions for a cultivated planet. Nature 478:337-342. http://dx.doi.org/10.1038/nature10452

Frampton, M. L. 1979. Enforcement of federal reclamation law in the Westlands Water District: a broken promise. University of California, Davis, Law Review 13(1):89-122.

Francis, C., G. Lieblein, S. Gliessman, T. A. Breland, N. Creamer, R. Harwood, L. Salomonsson, J. Helenius, D. Rickerl, R. Salvador, M. Wiedenhoeft, S. Simmons, P. Allen, M. Altieri, C. Flora, and R. Poincelot. 2003. Agroecology: the ecology of food systems. Journal of Sustainable Agriculture 22(3):99-118. http://dx.doi.org/10.1300/J064v22n03_10

Friedland, W. H. 2001. Reprise on commodity systems methodology. International Journal of Sociology of Agriculture and Food 9(1):82-103.

Gabriel, D., S. Sait, J. Hodgson, U. Schmutz, W. Kunin, and T. Benton. 2010. Scale matters: the impact of organic farming on biodiversity at different spatial scales. Ecology Letters 13:858-869. http://dx.doi.org/10.1111/j.1461-0248.2010.01481. $\underline{\mathrm{X}}$

Galt, R.E. 2008. Pesticides in export and domestic agriculture: reconsidering market orientation and pesticide use in Costa Rica. Geoforum 39(3):1378-1392. http://dx.doi.org/10.1016/ j.geoforum.2007.12.003

Getz, C., S. Brown, and A. Shreck. 2008. Class politics and agricultural exceptionalism in California's organic agriculture movement. Politics \& Society 36(4):478. http://dx.doi. org/10.1177/0032329208324709

Gliessman, S. R. 2007. Agroecology: the ecology of sustainable food systems. CRC Press, Boca Raton, Florida, USA.

Gliessman, S. R., R. E. Garcia, and M. A. Amador. 1981. The ecological basis for the application of traditional agricultural technology in the management of tropical agro-ecosystems. Agro-Ecosystems 7:173-185. http://dx.doi.org/10.1016/0304-3746 (81)90001-9

Godoy, R. 1994. The fiscal role of the Andean Ayllu. Man 21 (4):723-741. http://dx.doi.org/10.2307/2802905

Goodman, D., E. M. DuPuis, and M. K. Goodman. 2011. Alternative food networks: knowledge, place and politics. Routledge, London, UK.

Goodman, D., and M. Watts. 1997. Globalising food: agrarian questions and global restructuring. Routledge, London, UK.

Gordon, L. J., G. D. Peterson, and E. M. Bennett. 2008. Agricultural modifications of hydrological flows create ecological surprises. Trends in Ecology \& Evolution 23 (4):211-219. http://dx.doi.org/10.1016/j.tree.2007.11.011

Gottlieb, R., and A. Joshi. 2010. Food Justice. MIT Press, Cambridge, Massachussetts, USA.

GRAIN. 2011. New agricultural agreement in Argentina: a land grabber's instruction manual. [online] URL: http://www. grain.org/article/entries/4139-new-agricultural-agreement-inargentina-a-land-grabber-s-instruction-manual

Guthman, J. 2004. Agrarian dreams: the paradox of organic farming in California. University of California Press, Berkeley, CA, USA.

Haering, S. A., and S. B. Syed. 2009. Community food security in United States cities: a survey of the relevant scientific literature. Center for a Livable Future, Johns Hopkins Bloomberg School of Public Health, Baltimore, USA. [online] URL: http://www.jhsph.edu/sebin/s/c/FS_Literature\%20Booklet. pdf

Harrison, J. L. 2011. Pesticide drift and the pursuit of environmental justice. MIT Press, Cambridge, Massachussetts, USA.

Hazell, P., and S. Woods. 2008. Drivers of change in global agriculture. 367(1491):495. http://dx.doi.org/10.1098/rstb.2007.2166

Helfand, S. M., and E. S. Levine. 2004. Farm size and the determinants of productive efficiency in the Brazilian CenterWest. Agricultural Economics 31(2-3):241-249.

Herrero, M., P. K. Thornton, A. M. Notenbaert, S. Wood, S. Msangi, H. A. Freeman, D. Bossio, J. Dixon, M. Peters, J. van de Steeg, J. Lynam, P. P. Rao, S. Macmillan, B. Gerard, J. 
McDermott, C. Sere, and M. Rosegrant. 2010. Smart investments in sustainable food production: revisiting mixed crop-livestock systems. Science 327(5967):822-825. http:// dx.doi.org/10.1126/science.1183725

Hiddink, G. A., A. J. Termorshuizen, and A. H. C. Bruggen. 2010. Mixed cropping and suppression of soilborne diseases. Pages 119-146 in E. Lichtfouse, editor. Genetic Engineering, biofertilisation, soil quality and organic farming. Springer Netherlands, Dordrecht, Netherlands.

Holt-Giménez, E. 2006. Campesino-a-campesino: voices from Latin America's farmer to farmer movement for sustainable agriculture. Food First Books, Oakland, California, USA.

Holt-Giménez, E. 2007. The biofuel myths. International Herald Tribune 10(July 10).

Holt-Giménez, E., and R. Patel. 2009. Food rebellions!: crisis and the hunger for justice. Fahamu Books and Pambazuka, Oxford, UK.

Horrigan, L., R. Lawrence, and P. Walker. 2002. How sustainable agriculture can address the environmental and human health harms of industrial agriculture. Environmental health perspectives 10(5):445.

Iles, A., and R. Marsh. 2012. Nurturing diversified farming systems in industrialized countries: how public policy can contribute. Ecology and Society 17(4): 42. http://dx.doi. org/10.5751/ES-05041-170442

International Assessment of Agricultural Knowledge, Science and Technology for Development (IAAKSTD). 2009. Global report: agriculture at a crossroads. Island Press, Washington, D. C., USA.

Jaffee, D., and P. H. Howard. 2010. Corporate cooptation of organic and fair trade standards. Agriculture and Human Values 27(4):387-399. http://dx.doi.org/10.1007/s10460-009-9231-8

Jha, S., C. M. Bacon, S. M. Philpott, R. A. Rice, V. E. Méndez, P. Läderach. 2011. A review of ecosystem services, farmer livelihoods, and value chains in shade coffee agroecosystems. Pages 141-208 in Integrating agriculture, conservation and ecotourism: examples from the field. Springer, The Netherlands. [online] URL: http://www.springerlink.com/ content/q653558t4q567h1m/ http://dx.doi.org/10.1007/978-94-007-1309-3 4

Kaluski, D., E. Ophir, and T. Amede. 2002. Food security and nutrition - the Ethiopian case for action. Public health nutrition 5:373. http://dx.doi.org/10.1079/PHN2001313

Kearins, K., and E. Collins. 2012. Making sense of ecopreneurs' decisions to sell up. Business Strategy and the Environment 21(2):15. http://dx.doi.org/10.1002/bse.710
Khan, Z., C. Midega, J. Pittchar, J. Pickett, and T. Bruce. 2011 Pushpull technology: a conservation agriculture approach for integrated management of insect pests, weeds and soil health in Africa. International Journal of Agricultural Sustainability 9(1):162-170. http://dx.doi.org/10.3763/ijas.2010.0558

Kleijn, D., R. A. Baquero, Y. Clough, M. Diaz, J. De Esteban, F. Fernandez, D. Gabriel, F. Herzog, A. Holzschuh, R. Johl, E. Knop, A. Kruess, E. J. P. Marshall, I. Steffan-Dewenter, T. Tscharntke, J. Verhulst, T. M. West, and J. L. Yela. 2006. Mixed biodiversity benefits of agri-environment schemes in five European countries. Ecology Letters 9(3):243-254. http:// dx.doi.org/10.1111/j.1461-0248.2005.00869.x

Kloppenburg, J., S. Lezberg, K. De Master, G. W. Stevenson, and J. Hendrickson. 2000. Tasting food, tasting sustainability: defining the attributes of an alternative food system with competent, ordinary people. Human organization 59 (2):177-186.

Kremen, C., and A. Miles. 2012. Ecosystem services in biologically diversified versus conventional farming systems: benefits, externalities, and trade-offs Ecology and Society 17 (4): 40. http://dx.doi.org/10.5751/ES-05035-170440

Kremen, C., N. M. Williams, R. L. Bugg, J. P. Fay, and R. W. Thorp. 2004. The area requirements of an ecosystem service: crop pollination by native bee communities in California. Ecology Letters 7:1109-1119. http://dx.doi.org/10.1111/ j.1461-0248.2004.00662.x

Kristiansen, P., A. Taji, and J. Reganold. 2006. Organic agriculture: a global perspective. CSIRO Publishing, Collingwood, Australia.

Lal, R. 2004. Soil carbon sequestration impacts on global climate change and food security. Science 304 (5677):1623-1627. http://dx.doi.org/10.1126/science.1097396

La Via Campesina. 2009. Policy documents. International Operational Secretariat (IOS) of La Via Campesina, Jakarta, Indonesia. [online] URL: http://viacampesina.org/en/index/ php/publications-mainmenu-30

Letourneau, D. K., and S. G. Bothwell. 2008. Comparison of organic and conventional farms: challenging ecologists to make biodiversity functional. Frontiers in Ecology and the Environment 6(8):430-438. http://dx.doi.org/10.1890/070081

Li, T. M. 2011. Centering labor in the land grab debate. Journal of Peasant Studies 38(2):281-298. http://dx.doi. org/10.1080/03066150.2011.559009

Lin, B. B. 2007. Agroforestry management as an adaptive strategy against potential microclimate extremes in coffee agriculture. Agricultural and Forest Meteorology 144 (1-2):85-94. http://dx.doi.org/10.1016/j.agrformet.2006.12.009 
Liverman, D. M., and S. Vilas. 2006. Neoliberalism and the environment in Latin America. Annual Review of Environment and Resources 31:327-363. http://dx.doi.org/10.1146/ annurev.energy.29.102403.140729

Lynch, D. H., R. MacRae, and R. C. Martin. 2011. The carbon and global warming potential impacts of organic farming: does it have a significant role in an energy constrained world? Sustainability 3(2):322-362. http://dx.doi.org/10.3390/su3020322

Lyson, T. A. 2004. Civic agriculture: reconnecting farm, food, and community. Tufts University Press, Medford, MA, USA.

Marks, A. R., K. Harley, A. Bradman, K. Kogut, D. B. Barr, C. Johnson, N. Calderon, and B. Eskenazi. 2010. Organophosphate pesticide exposure and attention in young Mexican-American children: the CHAMACOS Study. Environmental health perspectives 118(12):1768. http://dx. doi.org/10.1289/ehp.1002056

McMichael, P. 2009. A food regime analysis of the "world food crisis'. Agriculture and Human Values 26(4):281. http:// dx.doi.org/10.1007/s10460-009-9218-5

McMichael, P. 2010. Agrofuels in the food regime. Journal of Peasant Studies 37(4):609-629 http://dx.doi. org/10.1080/03066150.2010.512450

Mendez, V. E., C. M. Bacon, M. Olson, K. S. Morris, and A. Shattuck. 2010. Agrobiodiversity and shade coffee smallholder livelihoods: a review and synthesis of ten years of research in Central America. The Professional Geographer 62(3):357-376. http://dx.doi.org/10.1080/00330124.2010.483638

Montgomery, D. R. 2007. Soil erosion and agricultural sustainability. Proceedings of the National Academy of Sciences of the United States of America 104 (33):13268-13272. http://dx.doi.org/10.1073/pnas.0611508104

Nagayets, O. 2005. Small farms: current status and key trends. Pages 355-367 in Research workshop and information brief for future small farms. International Food Policy Research Institute and Overseas Development Institute. [online] URL: http://citeseerx.ist.psu.edu/viewdoc/download?

$\underline{\text { doi }=10.1 \cdot 1.146 .4632 \& r e p=r e p 1 \& \text { type }=p d f}$

National Academy of Sciences. 2010. Drivers and constraints affecting the transition to sustainable farming practices. Pages 271-350 in Committee on twenty-first century systems agriculture, National Research Council. Toward sustainable agricultural systems in the $21^{s t}$ century. NAS Press, Washington, D. C., USA.

Naylor, R., and P. Ehrlich. 1997. Natural pest control services and agriculture. Pages 151-174 in G. Daily, editor. Nature's services: societal dependence on natural ecosystems. Island Press, Washington, D. C., USA.

Nestle, M. 2003. The ironic politics of obesity. Science 299 (5608):781.
Netting, R. 1993. Smallholders, householders: farm families and the ecology of intensive, sustainable agriculture. Stanford University Press, Stanford, CA, USA.

Osterberg, D., and D. Wallinga. 2004. Addressing externalities from swine production to reduce public health and environmental impacts. American Journal of Public Health 94(10):1703. http://dx.doi.org/10.2105/AJPH.94.10.1703

Payne, T. 2002. U.S. farmers markets- 2000, A study of emerging trends. U.S. Department of Agriculture, Agricultural Marketing Service, Transportation and Marketing Programs, Marketing Services Branch. [online] URL: http:// agmarketing.extension.psu.edu/ComFarmMkt/PDFs/ emerg trend frm mrkt.pdf

Pearson, C. J. 2007. Regenerative, semiclosed systems: a priority for twenty-first-century agriculture. Bioscience 57 (5):409-418. http://dx.doi.org/10.1641/B570506

Peña, D. G. 2011. Structural violence, historical trauma, and public health: the environmental justice critique of contemporary risk science and practice. Pages 203-218 in L. M. Burton, S. P. Kemp, M. Leung, S. A. Matthews, and D. T. Takeuchi. Communities, Neighborhoods, and Health. Springer, New York, NY, USA.

Perfecto, I., R. A. Rice, R. Greenberg, and M. E. Vandervoort. 1996. Shade coffee - a disappearing refuge for biodiversity. Bioscience 46(8):598-608. http://dx.doi.org/10.2307/1312989

Perfecto, I., J. Vandermeer, A. Mas, and L. S. Pinto. 2005. Biodiversity, yield, and shade coffee certification. Ecological Economics 54(4):435-446. http://dx.doi.org/10.1016/j. ecolecon.2004.10.009

Perfecto, I., J. Vandermeer, and A. Wright. 2009. Nature's matrix: linking agriculture, conservation and food sovereignty. Earthscan, London, UK.

Philpott, S. M., W. J. Arendt, I. Armbrecht, P. Bichier, T. V. Diestch, C. Gordon, R. Greenberg, I. Perfecto, R. ReynosoSantos, and L. Soto-Pinto. 2008b. Biodiversity loss in Latin American coffee landscapes: review of the evidence on ants, birds, and trees. Conservation Biology 22(5):1093-1105. http://dx.doi.org/10.1111/j.1523-1739.2008.01029.x

Philpott, S. M., B. B. Lin, S. Jha, and S. J. Brines. 2008a. A multi-scale assessment of hurricane impacts on agricultural landscapes based on land use and topographic features. Agriculture, Ecosystems \& Environment 128(1-2):12-20. http://dx.doi.org/10.1016/j.agee.2008.04.016

Pimentel, D. 2005. Environmental and economic costs of the application of pesticides primarily in the United States. Environment, Development and Sustainability 7: 229-252. http://dx.doi.org/10.1007/s10668-005-7314-2

Pimentel, D., S. Williamson, C. E. Alexander, O. GonzalezPagan, C. Kontak, and S. E. Mulkey. 2008. Reducing energy 
inputs in the US food system. Human Ecology 36(4):459-471. http://dx.doi.org/10.1007/s10745-008-9184-3

Pollan, M. 2006. The omnivore's dilemma: a natural history of four meals. Penguin Books, New York, USA.

Pretty, J. 1995. Regenerating agriculture: policies and practice for sustainability and self-reliance. Island Press, Washington D. C., USA.

Pretty, J. 2003. Social capital and the collective management of resources. Science 302:1912-1914. http://dx.doi. org/10.1126/science.1090847

Pretty, J., A. Noble, D. Bossio, J. Dixon, R. Hine, F. W. T. P. De Vries, and J. Morison. 2006. Resource-conserving agriculture increases yields in developing countries. Environmental Science \& Technolology 40(4):1114-1119. http://dx.doi.org/10.1021/es051670d

Princen, T. 2001. Distancing and the severing of feedback. Pages 103-131 in T. Princen, M. Maniates, and K. Conca, editors. Confronting consumption. MIT Press, Cambridge, MA, USA.

Pulido, L., and D. Peña. 1998. Environmentalism and positionality: the early pesticide campaign of the United Farm Workers' Organizing Committee, 1966-71. Race, Gender and Class 6(1):33-50.

Raynolds, L. T. 2004. The globalization of organic agro-food networks. World Development 32(5):725-743. http://dx.doi. org/10.1016/j.worlddev.2003.11.008

Reynolds, B. 2002. Black farmers in America, 1865-2000: the pursuit of independent farming and the role of cooperatives. United States Department of Agriculture. Rural Business Cooperative Service Research Report, Washington, D. C., USA.

Robbins, P., J. Hintz, and S. A Moore. 2010. Environment and society: a critical introduction. Wiley-Blackwell, West Sussex, UK.

Roling, N., and A. Wagemakers. 1998. Facilitating sustainable agriculture: participatory learning and adaptive management in times of environmental uncertainty. Cambridge University Press, New York, USA.

Rosset, P. M. 1999. The multiple functions and benefits of small farm agriculture. Policy brief no.4. Food First/ The Institute for Food and Development Policy, Oakland, California, USA. http://dx.doi.org/10.1057/palgrave. development.1110149

Rosset, P. M. 2008. Food sovereignty and the contemporary food crisis. Development 51(4):460-463. http://dx.doi. org/10.1057/dev.2008.48

Rosset, P. M., and M. E. Martínez-Torres. 2012. Rural social movements and agroecology: context, theory, and process.
Ecology and Society 17(3): 17. http://dx.doi.org/10.5751/ ES-05000-170317

Rosset, P. M., B. M. Sosa, A. M. R. Jaime, and D. R. A. Lozano. 2011. The campesino-to-campesino agroecology movement of ANAP in Cuba: social process methodology in the construction of sustainable peasant agriculture and food sovereignty. Journal of Peasant Studies 38(1):161-191. http:// dx.doi.org/10.1080/03066150.2010.538584

Rudel, T. K., R. Defries, G. Asner, and W. F. Laurance. 2009. Changing drivers of deforestation and new opportunities for conservation. Conservation Biology 23(6):1396-1405. http:// dx.doi.org/10.1111/j.1523-1739.2009.01332.x

Sayre, N. 2005. Ecological and geographical scale: parallels and potential for integration. Progress in Human Geography 29(3):276-290. http://dx.doi.org/10.1191/0309132505ph546oa

Sayre, N. F., L. Carlisle, L. Huntsinger, G. Fisher, and A. Shattuck. 2012. The role of rangelands in diversified farming systems: innovations, obstacles, and opportunities in the USA. Ecology and Society 17(4): 43. http://dx.doi.org/10.5751/ ES-04790-170443

Scherr, S. J., and J. A. McNeely. 2008. Biodiversity conservation and agricultural sustainability: towards a new paradigm of 'ecoagriculture' landscapes. Philosophical Transactions of the Royal Society B-Biological Sciences 363 (1491):477-494. http://dx.doi.org/10.1098/rstb.2007.2165

Seufert, V., N. Ramankutty, and J. A. Foley. 2012. Comparing the yields of organic and conventional agriculture. Nature 485:229-232. http://dx.doi.org/10.1038/nature11069

Sevilla-Guzmán, E. 2006. Agroecología y agricultura ecológica: Hacía una 're' construcción de la soberanía alimentaria. Revista Agroecología 1:7-18.

Shennan, C. 2008. Biotic interactions, ecological knowledge and agriculture. Philosophical Transactions of the Royal Society B-Biological Sciences 363(1492):717-739. http://dx. doi.org/10.1098/rstb.2007.2180

Shreck, A., C. Getz, and G. Feenstra. 2006. Social sustainability, farm labor, and organic agriculture: Findings from an exploratory analysis. Agriculture and Human Values 23(4):439-449. http://dx.doi.org/10.1007/s10460-006-9016-2

Smil, V. 2004. Enriching the earth: Fritz Haber, Carl Bosch, and the transformation of world food production. MIT Press, Cambridge, MA, USA.

Snapp, S., L. Gentry, and R. Harwood. 2010. Management intensity - not biodiversity - the driver of ecosystem services in a long-term row crop experiment. Agriculture, Ecosystems \& Environment 138(3-4):242-248. http://dx.doi.org/10.1016/ j.agee.2010.05.005 
Stoate, C., A. Baldi, P. Beia, N. D. Boatman, I. Herzon, A. van doorn, G. R. de Snoo, L. Rakosy, and C. Ramswell. 2009. Ecological impacts of early 21 st century agricultural change in Europe - a review. Journal of Environmental Management 91:22-46. http://dx.doi.org/10.1016/j.jenvman.2009.07.005

Tegtmeier, E., and M. Duffy, M. 2005. External costs of agricultural production in the United States. International Journal of Agricultural Sustainability 2(1):a. http://dx.doi. org/10.1080/14735903.2004.9684563

Tilman, D., K. G. Cassman, P. A. Matson, R. Naylor, and S. Polasky. 2002. Agricultural sustainability and intensive production practices. Nature 418(6898):671-677. http://dx. doi.org/10.1038/nature01014

Tilman, D., J. Fargione, B. Wolff, C. D'Antonio, A. Dobson, R. Howarth, D. Schindler, W. H. Schlesinger, D. Simberloff, and D. Swackhamer. 2001. Forecasting agriculturally driven global environmental change. Science 292(5515):281-284. http://dx.doi.org/10.1126/science.1057544

Tscharntke, T., A. M. Klein, A. Kruess, I. Steffan-Dewenter, and C. Thies. 2005. Landscape perspectives on agricultural intensification and biodiversity-ecosystem service management. Ecology Letters 8(8):857-874. http://dx.doi.org/10.1111/ j.1461-0248.2005.00782.x

United State Department of Agriculture. 2011a. Farmers' markets and local food marketing. [online] URL: http://www. ams.usda.gov/AMSv1.0/farmersmarkets

United States Department of Agriculture. 2011b. Organic agriculture: data set. [online] URL: http://www.ers.usda.gov/ Data/Organic/

VanderHoff Boersma, F. 2009. The urgency and necessity of a different type of market: the perspective of producers organized within the fair trade market. Business Ethics 89(1 (Supplement 1)):51-61. http://dx.doi.org/10.1007/s10551-008-9766-4

Vandermeer, J. H. 1992. The ecology of intercropping. Cambridge University Press, Cambridge, UK. http://dx.doi. org/10.1017/CBO9780511623523

Von Braun, J., and R. Meinzen-Dick. 2009. Land grabbing by foreign investors in developing countries: risks and opportunities. Policy brief 13. International Food Policy Research Institute (IFPRI), Washington, D. C., USA.

Walker, R. 2004. The conquest of bread: 150 years of agribusiness in California. New Press, New York, USA.

Watts, M., and P. D. Little. 1994. Life under contract: contract farming, agrarian restructuring, and flexible accumulation. Pages 21-77 in P. D. Little, and M. J. Watts, editors. Living under contract: contract farming and agrarian transformation in sub-Saharan Africa. University of Wisconsin Press, Madison, USA.
Welch, R. M., and R. D. Graham. 1999. A new paradigm for world agriculture: meeting human needs - productive, sustainable, nutritious. Field Crops Research 60(1-2):1-10. http://dx.doi.org/10.1016/S0378-4290(98)00129-4

Wezel, A., S. Bellon, T. Dore, C. Francis, D. Vallod, and C. David. 2009. Agroecology as a science, a movement and a practice. A review. Agronomy for Sustainable Development 29(4):503-515. http://dx.doi.org/10.1007/978-94-007-0394-0 3

Whatmore, S., P. Stassart, and H. Renting. 2003. Guest editorial: what's alternative about alternative food networks. Environment and Planning A 35(3):389-391.

Wilcove, D. S., and L. P. Koh. 2010. Addressing the threats to biodiversity from oil-palm agriculture. Biodiversity and Conservation 19(4):999-1007. http://dx.doi.org/10.1007/ s10531-009-9760-x

Willer, H., and L. Kilcher, editors. 2011. The world of organic agriculture - statistics and emerging trends 2011. International Federation of Organic Agriculture Movements (IFOAM), Bonn, Germany, and Research Institute of Organic Agriculture (FiBL), Frick, Switzerland.

Windfuhr, M., and J. Jonsén. 2005. Food sovereignty: towards democracy in localized food systems. Practical Action Publishing, Warwickshire, United Kingdom.

Wirth, C., R. Strochlic, and C. Getz. 2007. Hunger in the fields: food insecurity among farmworkers in Fresno County. California Institute for Rural Studies, Davis, California. [online] URL: http://www.cirsinc.org/index.php/publications/ archives/category/8-rural-health.html?download=46\%3Ahungerin-the-fields-food-insecurity-among-farmworkers-in-fresno-county

Wise, T. A. 2011. Mexico: the cost of US dumping. NCLA: report on the Americas. January/February: 47-50.

Wittman, H. 2009. Reworking the metabolic rift: La Vía Campesina, agrarian citizenship, and food sovereignty. Journal of Peasant Studies 36(4):819-840. http://dx.doi. org $/ 10.1080 / 03066150903353991$

Wittman, H., A. Desmarais, and N. Wiebe, editors. 2010. Food sovereignty: reconnecting food, nature and community. Fernwood Publishing, Halifax and Winnipeg, Canada; Food First Books, Oakland, California, USA; Pambazuka Press, Oxford, UK.

Wolford, W. 2008. Environmental justice and agricultural development in the Brazilian Cerrado. Pages 213-239 in D. Carruthers, editor. Environmental justice in Latin America. MIT Press, Cambridge, Massachussetts, USA.

World Health Organization (WHO). 2012. Obesity and overweight. Fact sheet 311. [online] URL: http://www.who. int/mediacentre/factsheets/fs311/en/ 
Xolocotzi, E. H. 1985. Maize and man in the greater Southwest. Economic Botany 39(4):416-430. http://dx.doi. org/10.1007/BF02858749

Zezima, K. 2009. Food stamps, now paperless, are getting easier to use at farmers' markets. New York Times:A10.

Zezima, K. 2011. As farmers' markets go mainstream, some fear a glut. New York Times:A12.

Zhang, W., T. H. Ricketts, C. Kremen, K. Carney, and S. M. Swinton. 2007. Ecosystem services and dis-services to agriculture. Ecological Economics 64:253-260. http://dx.doi. org/10.1016/j.ecolecon.2007.02.024 